RESEARCH ARTICLE

\title{
Plant diversity and soil characteristics of the Ussangoda serpentine site
}

\author{
H.A.S. Weerasinghe and M.C.M. Iqbal ${ }^{*}$ \\ Plant Biology, Institute of Fundamental Studies, Hantana Road, Kandy.
}

Revised: 03 May 2011 ; Accepted: 20 May 2011

\begin{abstract}
Serpentine soils are derived from the weathering of serpentine and ultramafic rocks, which have a high content of ferromagnesian minerals. The high content of heavy metals in serpentine soils alter their physical and chemical properties making them unsuitable for plant growth. There are six serpentine sites in Sri Lanka and the Ussangoda site is on the southern coast in Hambantota. The moisture content, organic matter and cation exchange capacity (CEC) are low in serpentine soils. The available calcium ( $\mathrm{Ca}$ ) content is low and the magnesium $(\mathrm{Mg})$ content is relatively high. The $\mathrm{Ca}$ to $\mathrm{Mg}$ ratio is 0.60 , which is typical for serpentine soils. Two distinct forms of vegetation grow on the Ussangoda serpentine soil. The large plain is covered by stunted, prostrate species with an extensive root system. Patches of shrubs and trees occur on the plains as small islands. The serpentine flora is sharply demarcated from the surrounding non-serpentine flora by their growth habit. The number of plant families and species is lower in the serpentine soil than in the adjacent non-serpentine areas. Four families comprising six species grew only on the serpentine soil. Five species growing in the serpentine soil contained $560-830$ ppm of nickel (Ni) in their tissues. Hybanthus enneaspermus had $1800 \mathrm{ppm}$ of nickel. Two species, Vernonia zeylanica and Scolopia acuminata, are endemic to Sri Lanka.
\end{abstract}

Keywords: Biodiversity, Evolvulus alsinoides, heavy metals, Hybanthus enneaspermus, serpentine, Ussangoda.

\section{INTRODUCTION}

Serpentine soils occur in isolated patches all over the world, particularly along continental margins. They are derived from serpentine rocks composed of serpentine minerals and ultramafic rocks, which have a high content of ferromagnesian minerals (Brooks, 1987). The weathering of these rock types enriches the soil with $\mathrm{Mg}, \mathrm{Fe}$ and other heavy metals such as $\mathrm{Ni}$ and $\mathrm{Co}$. These metals change the physical and chemical properties of the soil to form an unfavourable and hostile environment for plant growth. Over time, plant species have adapted to these unusual soil conditions producing unique associations between the soil and plants. They can be regarded as living laboratories for studying evolutionary biology and adaptations by the plant species to the extreme environments peculiar to serpentine soils.

Very little is known of the geology and flora of serpentine sites in Southeast Asia. In India, an ultramafic site was reported in the State of Orissa (Brooks, 1987). The serpentine areas in the Malay Archipelago are well documented and many endemic species have been identified (Brooks, 1987; Proctor 2003). The soil characteristics of the ultramafic sites in Malaysia, Indonesia and Philippines have been compared by Brearley (2005). Geological studies in Sri Lanka have shown six serpentinite sites atUssangoda, Indikolapelessa, Ginigalpelessa, Katupota, Yodhagannawa and Rupaha. These sites lie close to a Precambrian suture zone between the lithotectonic units, the Vijayan and Highland series (Dissanayake \& Van Riel, 1978; Munasinghe \& Dissanayake, 1979; Munasinghe \& Dissanayake, 1980). Of these sites the geochemistry of the Uda-Walawe serpentine site has been described (Dissanayake \& Van Riel, 1978; Dissanayake, 1982).

Ultramafic soils are generally shallow with a high $\mathrm{Mg}$ to $\mathrm{Ca}$ ratio, deficient in essential plant nutrients and contain potentially toxic concentrations of heavy metals (Proctor \& Woodell, 1975; Brooks 1987). The rocky nature of the soil and low clay and organic matter content provide a highly permeable soil with low water holding capacity. The exchangeable Mg concentrations are high and exchangeable $\mathrm{Ca}$ concentrations are low in the soil, which is deficient in essential plant nutrients N, P and K (Kruckeberg,1984). The vegetation on serpentine soils

* Corresponding author (mcmif2003@yahoo.com) 
have adapted morphologically and physiologically to this environment. Morphologically plants are dwarfed with narrow, glaucescent thick leaves, strong sclerenchyma development and enlarged root system (Kruckeberg, 1984). Physiologically they are able to tolerate the heavy metal presence in the soil by absorption and sequestration or exclusion. Thus serpentine soils are a unique ecological niche, which is poor in diversity of plant species.

The flora of Ussangoda was first described by Brooks (1987), who on a visit to the island referred to the Ussangoda serpentine site: "At Welipatanwila, the heavily laterised ultramafics are almost completely devoid of vegetation except for a scattering of a small blue-flowered herb, Evolvulus alsinoides. The boundary of the serpentine is marked by low thorn bushes interspersed with Opuntia species". In a subsequent study (Seneviratne et al., 2000), 14 plant species were identified all of which accumulated over $100 \mathrm{ppm}$ of Ni. Rajakaruna and Bohm (2002) studied nine plant species growing on the Ussangoda serpentine soil and the soil chemistry from their root zones. Their study found three species, which hyperaccumulated over $1000 \mathrm{ppm}$ of $\mathrm{Ni}$ from the soil. In a recent study (Iqbal et al., 2006) 29 species of flowering plants, which included trees, shrubs, vines and prostate plants growing within the Ussangoda serpentine site were identified. Cassia kleinii was identified as a Ni hyper-accumulator. In the last 20 years, few studies were devoted to study this unique habitat and much work remains to be done.

For a comprehensive study of the Ussangoda serpentine site, it is necessary to determine the diversity of plant species, their physiological adaptations to the adverse soil environment and the soil characteristics contributing to their adaptations. This would subsequently assist in the study of the other serpentine sites in Sri Lanka and potentially contribute towards identifying heavy metal hyper-accumulating species. The objective of this study is to determine the important physical and chemical characteristics of the Ussangoda soil, its consequence on the flora and diversity of the flora in relation to the surrounding non-serpentine areas.

\section{METHODS AND MATERIALS}

Site description: The serpentine study site at Ussangoda (Figure 1) is a flat plain (approximately $1 \mathrm{~km}^{2}$ ) located close to the Nonagama junction on the Matara Hambantota highway (latitude $06^{\circ} 05^{\prime} \mathrm{N}$, longitude $80^{\circ}$ $\left.59^{\prime} \mathrm{E}\right)$. The southern boundary of the plain is a cliff, approximately $30 \mathrm{~m}$ amsl, overlooking the Indian Ocean. The highest point on the plain is $34.5 \mathrm{~m}$ amsl.
Climate: The mean annual temperature is $27.9^{\circ} \mathrm{C}$ with a mean range of $31.1-24.6^{\circ} \mathrm{C}$. Daytime temperature during field visits reached $35.8^{\circ} \mathrm{C}$. The annual rainfall is less than $1250 \mathrm{~mm}$ (mainly from October - January) with more than 5 dry months with less than $50 \mathrm{~mm}$ rainfall (IUCN, 2004).

Soil analysis: Soil samples were collected according to the stratified random sampling technique to represent the 10,20 and $30 \mathrm{~m}$ contours. Each sample was collected from below the soil surface to a depth of $10 \mathrm{~cm}$ and stored in labelled polythene bags. All the samples were analysed separately. The samples were air-dried for $1 \mathrm{wk}$ at room temperature and passed through a $2 \mathrm{~mm}$ sieve. Soil moisture was determined by drying $5 \mathrm{~g}$ of soil to a constant mass in an oven at $105{ }^{\circ} \mathrm{C}$ for $24 \mathrm{~h}$ and cooling it in a desiccator for $30 \mathrm{~min}$. To determine the $\mathrm{pH}, 20 \mathrm{~mL}$ of de-ionized water or calcium chloride was added to $10 \mathrm{~g}$ of soil and stirred 4-5 times within $30 \mathrm{~min}$. The suspension was allowed to settle for $30 \mathrm{~min}$ and the $\mathrm{pH}$ of the supernatant determined. Soil conductivity was measured in a suspension from mixing $40 \mathrm{~g}$ of soil and $80 \mathrm{~mL}$ de-ionized water. The above methods are described in Kalra \& Maynard (1991).

Cation exchange capacity (CEC) of the soil was determined according to Anderson \& Ingram (1993). Airdried soil was shaken with $1 \mathrm{M}$ potassium chloride for 5 min and repeatedly centrifuged until the supernatant was clear. Ethanol was added to the filtrate and centrifuged until the supernatant to be discarded was clear. To this $1 \mathrm{M}$ ammonium acetate was added, and the mixture shaken and centrifuged until the supernatant was clear. The supernatant volume was made up to $100 \mathrm{~mL}$ with ammonium acetate. The potassium concentration was measured by the atomic absorption spectrophotometer (AAS). Soil organic matter was determined by percentage loss-on-ignition (LOI) after heating $5 \mathrm{~g}$ of oven-dried soil in a crucible to $375^{\circ} \mathrm{C}$ in a muffle furnace for $16 \mathrm{~h}$ (Kalra \& Maynard, 1991). Soil exchangeable cations (Ca, Mg, $\mathrm{Na} \& \mathrm{~K}$ ) were extracted by shaking $5 \mathrm{~g}$ of air-dried soil with $25 \mathrm{~mL}$ of neutral $1 \mathrm{~N}$ ammonium acetate for $30 \mathrm{~min}$, filtered (Whatman no.42) and the filtrate analysed by AAS (AESL, 1999). Soil micronutrients were extracted by adding $50 \mathrm{~mL}$ of diethylene triamine penta acetic acid (DTPA) to $2.5 \mathrm{~g}$ of air dried soil in $250 \mathrm{~mL}$ open conical flasks and filtered. The micronutrients in the filtrate were measured by AAS (Amacher, 1996).

Plant material: Plants with their reproductive structures were identified after comparison with specimens in the National Herbarium of the Royal Botanic Gardens, Peradeniya. Herbarium sheets were prepared of the 


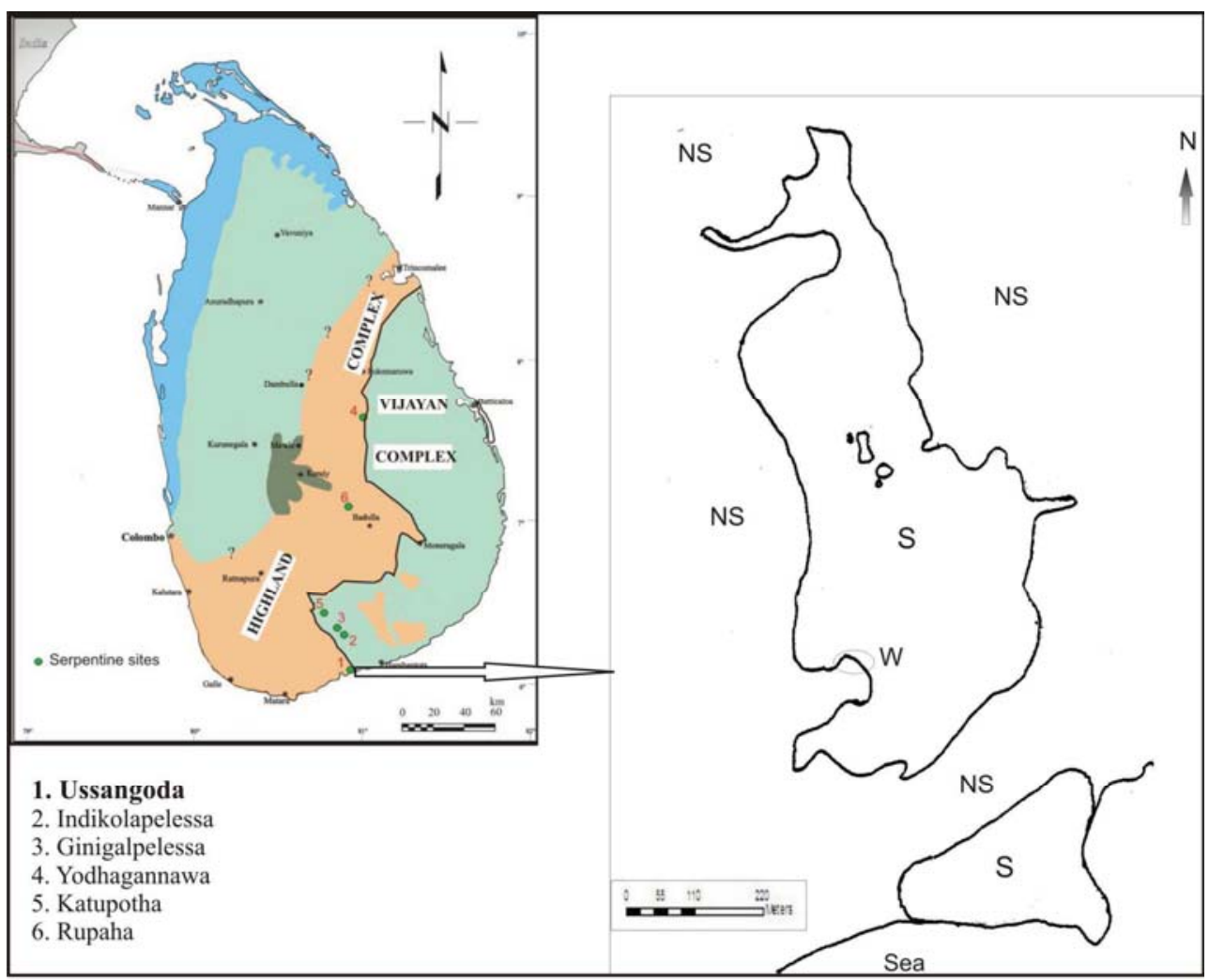

Figure 1: Map of Sri Lanka showing the serpentine sites and an enlarged view of the Ussangoda serpentine site. $(\mathrm{S}=$ Serpentine, $\mathrm{NS}=$ Non-serpentine, $\mathrm{W}=$ Water hole $)$.

collected species. Plant samples for analysis were bagged and labelled in polythene bags.

Plant analysis: Plant samples were cleaned with a nylon brush under running tap water to remove adhered soil and then washed with ethylene diamine tetra-acetic acid (EDTA) for $1 \mathrm{~min}$ and rinsed thrice with de-ionized water to remove any surface bound metals. The samples were dried at $80{ }^{\circ} \mathrm{C}$ for $24 \mathrm{~h}$ in a forced air oven and ground in a plant grinder and stored in airtight bags. Samples of $500 \mathrm{mg}$ were ashed in a muffle furnace at $550{ }^{\circ} \mathrm{C}$ for $8 \mathrm{~h}$ and the ash dissolved in $5 \mathrm{~mL}$ of concentrated $\mathrm{HCl}$ and volume made up to $50 \mathrm{~mL}$ with distilled water. The macro and micro nutrients were determined by AAS.

Statistical analysis: Statistical analysis was carried out using the Minitab 14 statistical software package. Oneway ANOVA along with multiple comparison of means using Tukey's test was performed.

\section{RESULTS}

The serpentine plain has isolated patches of dense shrubs and trees, and rocky outcrops. The plants on the plains are prostrate, stunted with an extensive root system. The plain is clearly demarcated from the surrounding nonserpentine area by large shrubs and trees. The surface soil is a fine reddish dust with small lateritic stones.

\section{Soil characteristics}

The serpentine and non-serpentine soils showed significant differences in their physical and chemical properties. Within the serpentine site there are two contrasting vegetation types, the prostrate stunted species and the patches of shrubs and trees. The available moisture was low in the serpentine soil while the shrub patches had significantly higher moisture approaching that of the non-serpentine soil. This was not associated 
Table 1: Physical and chemical properties of the serpentine soil in Ussangoda and the adjacent non-serpentine soil (mean values $\pm \mathrm{SE}$ )

\begin{tabular}{|c|c|c|c|c|}
\hline Soil parameter & $\begin{array}{c}\text { Serpentine } \\
\left(\text { Area }=1 \mathrm{~km}^{2}\right)\end{array}$ & $\begin{array}{c}\text { Island }^{1} 1 \\
\left(\text { Area }=2141 \mathrm{~m}^{2}\right)\end{array}$ & $\begin{array}{c}\text { Island }^{1} 2 \\
\left(\text { Area }=764 \mathrm{~m}^{2}\right)\end{array}$ & Non-serpentine \\
\hline $\mathrm{n}$ & 14 & 9 & 7 & 6 \\
\hline Moisture (\%) & $4.4 \pm 0.26^{\mathrm{a}}$ & $7.01 \pm 0.64^{b}$ & $8.92 \pm 0.42^{\mathrm{b}, \mathrm{c}}$ & $10.61 \pm 1.6^{\mathrm{c}}$ \\
\hline Organic matter (\%) & $2.96 \pm 0.26^{\mathrm{a}}$ & $5.46 \pm 0.42^{\mathrm{b}}$ & $5.84 \pm 0.23 \mathrm{~b}, \mathrm{c}$ & $4.31 \pm 0.24^{\mathrm{a}, \mathrm{b}}$ \\
\hline \multicolumn{5}{|l|}{$\begin{array}{l}(\mathrm{cmol}(+) / \mathrm{kg} \text { of } \\
\text { dry soil) }\end{array}$} \\
\hline $\mathrm{n}$ & 6 & 4 & 4 & 5 \\
\hline $\mathrm{pH}$ & $5.32 \pm 0.21^{\mathrm{a}}$ & $5.95 \pm 0.13$ a,b & $6.23 \pm 0.21^{b}$ & $7.3 \pm 0.19^{c}$ \\
\hline $\begin{array}{l}\text { Conductivity } \\
\text { (micro-siemens) }\end{array}$ & $61 \pm 6.54^{\mathrm{a}}$ & $55.8 \pm 9.54^{\mathrm{a}}$ & $130 \pm 28^{b}$ & $162.4 \pm 10.9^{b}$ \\
\hline \multicolumn{5}{|l|}{ Exchangeable cations } \\
\hline $\mathrm{n}$ & 29 & 9 & 7 & 8 \\
\hline $\mathrm{Ca}(\mu \mathrm{g} / \mathrm{g})$ & $187 \pm 27.5^{a}$ & $645 \pm 84.8^{b}$ & $905 \pm 135^{b}$ & $2911 \pm 650^{c}$ \\
\hline $\operatorname{Mg}(\mu \mathrm{g} / \mathrm{g})$ & $311 \pm 48.3^{\text {a }}$ & $352 \pm 50.3^{a}$ & $456 \pm 35.7^{\mathrm{a}}$ & $519 \pm 53.2^{a}$ \\
\hline $\mathrm{Ca} / \mathrm{Mg}$ & 0.601 & 1.832 & 1.984 & 5.608 \\
\hline $\mathrm{K}(\mu \mathrm{g} / \mathrm{g})$ & $140 \pm 12.2^{\mathrm{a}}$ & $321 \pm 38.3^{b}$ & $314 \pm 21.7^{b}$ & $338 \pm 93.9^{b}$ \\
\hline $\mathrm{Na}(\mu \mathrm{g} / \mathrm{g})$ & $67 \pm 16.8^{a}$ & $50 \pm 9.44^{a}$ & $67 \pm 10.1^{a}$ & $636 \pm 207^{b}$ \\
\hline \multicolumn{5}{|c|}{ Available micro-elements } \\
\hline $\mathrm{n}$ & 31 & 9 & 7 & 8 \\
\hline $\mathrm{Ni}(\mu \mathrm{g} / \mathrm{g})$ & $101 \pm 12.1^{\mathrm{a}}$ & $137 \pm 12.14^{\mathrm{a}}$ & $151 \pm 7.8^{\mathrm{a}}$ & $4 \pm 1.13^{b}$ \\
\hline $\mathrm{Fe}(\mu \mathrm{g} / \mathrm{g})$ & $65 \pm 4.61^{a}$ & $56 \pm 3.19^{a}$ & $46 \pm 3.35^{\mathrm{a}}$ & $62 \pm 15.2^{a}$ \\
\hline $\mathrm{Mn}(\mu \mathrm{g} / \mathrm{g})$ & $42 \pm 6.96^{\mathrm{a}}$ & $15 \pm 1.73^{b}$ & $10 \pm 0.94^{b}$ & $19 \pm 4.18^{\mathrm{a}, \mathrm{b}}$ \\
\hline
\end{tabular}

${ }^{1}$ Island refers to the patches of shrubs and trees on the serpentine plains. $n=$ number of samples.

Figures followed by different letters in the same row are significantly different at $\mathrm{p}<0.05$.

with the organic matter content of the soils (Table 1). The CEC of the serpentine soils was also significantly lower. The $\mathrm{pH}$ of the serpentine soil tended towards acidity and the non-serpentine soil was significantly neutral (Table 1). The conductivity of the non-serpentine soil was significantly higher than that of the serpentine soil and the soil of the shrub patches.

The chemical properties of the serpentine soil showed highly significant differences from the nonserpentine soil. The $\mathrm{Ca}$ content of the non-serpentine soil was 3 to 15 times higher than that in the shrub patches and the serpentine soil respectively. Although $\mathrm{Mg}$ content of the different soils were comparably similar, the difference in $\mathrm{Ca}$ was reflected in the $\mathrm{Ca}: \mathrm{Mg}$ ratio (Table 1). The serpentine soil has a characteristic value of 0.60 . The shrub patches with a higher Ca content of 3 to 4 times that of the serpentine soil have a $\mathrm{Ca}: \mathrm{Mg}$ ratio higher than that of the serpentine soils. Similarly the Ni content was much higher than in the non-serpentine soils. Fe does not show a significant difference between the soil types and Mn was high in the serpentine soil (Table 1).

\section{Flora}

In this study the diversity of plant families and species in Ussangoda is based on a field survey of the flora on the serpentine soil and a previous survey conducted by the International Union for Conservation of Nature (IUCN, 2004) on all the species in the Ussangoda region.

This study identified 26 plant families on the serpentine soil. Of these, nine families with 12 species occur on the serpentine plain (Table 2). These species are prostrate, dwarfed or stunted, with small leaves, thick sclerenchymatous stems and extensive root systems. The prostrate species E. alsinoides, had three colour morphs: white, pale purple and dark blue. They occurred either in close proximity or spread apart on the plains. The dominant family on the serpentine plains was Fabaceae with three species. The other families occur in patches of shrubs and trees on the serpentine plain. 
Table 2: Nickel (Ni) content (mean $\pm \mathrm{SE}$ ) in some prostrate plants on the Ussangoda serpentine plain

\begin{tabular}{lllc}
\hline Name of the plant & Family & $\begin{array}{l}\text { Plant } \\
\text { part }\end{array}$ & $\begin{array}{c}\text { Nickel }(\mu \mathrm{g} / \mathrm{g} \\
\text { dry weight })\end{array}$ \\
\hline $\begin{array}{l}\text { Hybanthus enneaspermus } \\
\text { Evolvulus alsinoides }\end{array}$ & Violaceae & Lvs+sh & $1828 \pm 106$ \\
Euphorbia thymifolia & Convolvulaceae & Lvs + sh & $828 \pm 36$ \\
Cassia kleinii & Fabaceae & Lvs + sh & $745 \pm 67$ \\
Desmodium triflorum & Fabaceae & not determined & $652 \pm 23$ \\
Crotolaria sp. & Fabaceae & \multicolumn{2}{c}{ not determined } \\
Vernonia cinerea & Asteraceae & Lvs + sh & $561 \pm 14$ \\
Eragrostis sp. & Poaceae & Lvs & $233 \pm 8$ \\
Frimbristylis ovata & Cyperaceae & Lvs & $220 \pm 2$ \\
Frimbristylis falcata & Cyperaceae & Lvs & $73 \pm 19$ \\
\hline
\end{tabular}

Lvs $=$ Leaves, $\mathrm{sh}=$ shoots

The species recorded in the IUCN plant survey were compared with the species identified in this study. Five families with seven species growing only on the serpentine soil were recorded, which were not recorded by the IUCN study (IUCN 2004) in the Ussangoda region (Table 3). Of these Violaceae occurs on the plains and species of the other four families occur as shrubs or trees on the serpentine site. The diversity of families and their species was low on the serpentine soil. The survey of species has identified 16 species growing only on the serpentine soil and 44 species growing on serpentine and non-serpentine soil in Ussangoda (Table 3). The habits of these species were climbers, herbs, shrubs and trees. Monocotyledons were confined to Cyperaceae and Poaceae with four species. Of the 31 families on serpentine soil, Fabaceae included six species, Capparaceae and Malvaceae five species each and the rest had three species or less. In contrast, the diversity of species within the families was greater on the non-serpentine region of Ussangoda. Fabaceae had the most with 14 species while 10 families had three or more species.

Five species growing on the serpentine soil showed $\mathrm{Ni}$ accumulation. The species E. alsinoides, Euphorbia thymifolia, C. kleinii, and Vernonia cinerea accumulated $560-830 \mu \mathrm{g} / \mathrm{g}$ (dry weight) of nickel in their tissues while Hybanthus enneaspermus was a hyperaccumulator (Table 2). Although Fimbristylis ovata showed low nickel accumulation on the serpentine soil, under experimental hydroponic conditions with $\mathrm{Ni}$, levels of $2000 \mu \mathrm{g} / \mathrm{g}$ (dry weight) were detected (unpublished data, M.C.M. Iqbal).

Table 3: Plant species and their families found on serpentine soil and non-serpentine regions in Ussangoda (habit: $\mathrm{H}$ - herb, $\mathrm{S}$ - shrub, C - climber, $\mathrm{T}$ - tree).

\begin{tabular}{|c|c|c|c|c|c|}
\hline Families & Habit & Species & $\begin{array}{l}\text { Only on } \\
\text { serpentine } \\
\text { soil }\end{array}$ & $\begin{array}{c}\text { On } \\
\text { serpentinite } \\
\text { and non- } \\
\text { serpentinite } \\
\text { soils }\end{array}$ & $\begin{array}{c}\text { Source } \\
(\text { Ref no.) } \\
\mathrm{P}= \\
\text { present } \\
\text { survey }\end{array}$ \\
\hline Apocynaceae & $\mathrm{H}$ & Carissa spinarum & & $\mathrm{X}$ & $\mathrm{P}$ \\
\hline Asclepiadaceae & S & Calotropis gigantea & & $\mathrm{X}$ & $\mathrm{P}$ \\
\hline Asparagaceae & $\mathrm{C}$ & Asparagus racemosus & & $\mathrm{X}$ & $\mathrm{P}$ \\
\hline \multirow[t]{2}{*}{ Asteraceae } & $\mathrm{H}$ & Eupatorium odoratum & & $\mathrm{X}$ & $\mathrm{P}$ \\
\hline & $\mathrm{H}$ & Vernonia cinerea & & $\mathrm{X}$ & $\mathrm{P}$ \\
\hline Boraginaceae & $\mathrm{S}$ & Ehretia laevis & $\mathrm{X}$ & & $\mathrm{P}$ \\
\hline Cactaceae & $\mathrm{H}$ & Opuntia sp. & & $\mathrm{X}$ & $1, \mathrm{P}$ \\
\hline
\end{tabular}




\begin{tabular}{|c|c|c|c|c|c|}
\hline \multirow[t]{5}{*}{ Capparaceae } & S & \multicolumn{2}{|l|}{ Capparis pedunculosa } & $X$ & $P$ \\
\hline & S & \multicolumn{2}{|l|}{ Capparis rotundifolia } & $\mathrm{X}$ & $\mathrm{P}$ \\
\hline & S & \multicolumn{2}{|l|}{ Capparis sepiaria } & $\mathrm{X}$ & $\mathrm{P}$ \\
\hline & S & \multicolumn{2}{|l|}{ Capparis zeylanica } & $\mathrm{X}$ & $\mathrm{P}$ \\
\hline & S & Maerua arenaria & $\mathrm{X}$ & & $P$ \\
\hline Celastraceae & S & Maytenus emarginata & & $\mathrm{X}$ & $\mathrm{P}$ \\
\hline \multirow[t]{2}{*}{ Convolvulaceae } & $\mathrm{H}$ & Evolvulus alsinoides & & $\mathrm{X}$ & $1,10,11, \mathrm{P}$ \\
\hline & $\mathrm{H}$ & Ipomoea pes-caprae & $\mathrm{X}$ & & $\mathrm{P}$ \\
\hline \multirow[t]{3}{*}{ Cyperaceae } & $\mathrm{H}$ & Fimbristylis falcata & $\mathrm{X}$ & & $10,11, \mathrm{P}$ \\
\hline & $\mathrm{H}$ & Fimbristylis monticola & $\mathrm{X}$ & & $\mathrm{P}$ \\
\hline & $\mathrm{H}$ & Frimbistylis ovata & $\mathrm{X}$ & & $\mathrm{P}$ \\
\hline \multirow[t]{3}{*}{ Euphorbiaceae } & $\mathrm{H}$ & Euphorbia hirta & & $\mathrm{X}$ & $\mathrm{P}$ \\
\hline & $\mathrm{H}$ & Euphorbia thymifolia & & $\mathrm{X}$ & $P$ \\
\hline & $\mathrm{S}$ & Flueggea leucopyrus & & $\mathrm{X}$ & $\mathrm{P}$ \\
\hline \multirow[t]{6}{*}{ Fabaceae } & $\mathrm{C}$ & Acacia caesia & & $\mathrm{X}$ & $\mathrm{P}$ \\
\hline & $\mathrm{T}$ & Cassia auriculata & & $\mathrm{X}$ & $11, \mathrm{P}$ \\
\hline & $\mathrm{H}$ & Cassia kleinii & $X$ & & $\mathrm{P}$ \\
\hline & $\mathrm{H}$ & Crotolaria tecta & & $\mathrm{X}$ & $\mathrm{P}$ \\
\hline & $\mathrm{H}$ & Desmodium sp. & & $\mathrm{X}$ & $11, \mathrm{P}$ \\
\hline & S & Dichrostachys cinerea & & $\mathrm{X}$ & $\mathrm{P}$ \\
\hline \multirow[t]{3}{*}{ Flacourtiaceae } & & Casearia zeylanica & $X$ & & $\mathrm{P}$ \\
\hline & S & Flacourtia indica & $\mathrm{X}$ & & $\mathrm{P}$ \\
\hline & $\mathrm{T}$ & Scolopia acuminata & & $\mathrm{X}$ & $\mathrm{P}$ \\
\hline Linaceae & $\mathrm{T}$ & Hugonia mystax & & $\mathrm{X}$ & $\mathrm{P}$ \\
\hline Loranthaceae & S & Dendrophthoe falcata & & $\mathrm{X}$ & $\mathrm{P}$ \\
\hline \multirow[t]{5}{*}{ Malvaceae } & $\mathrm{H}$ & Abutilon indicum & & $\mathrm{X}$ & $P$ \\
\hline & $\mathrm{H}$ & Pavonia odorata & & $\mathrm{X}$ & $\mathrm{P}$ \\
\hline & $\mathrm{H}$ & Sida acuta & & $\mathrm{X}$ & $\mathrm{P}$ \\
\hline & $\mathrm{H}$ & Sida cordifolia & & $\mathrm{X}$ & $\mathrm{P}$ \\
\hline & $\mathrm{H}$ & Sida rhombifolia & $\mathrm{X}$ & & $\mathrm{P}$ \\
\hline Melastomataceae & S & Memecylon umbellatum & & $\mathrm{X}$ & $\mathrm{P}$ \\
\hline Melliaceae & $\mathrm{T}$ & Azadirachta indica & & $\mathrm{X}$ & $\mathrm{P}$ \\
\hline Menispermaceae & $\mathrm{C}$ & Pachygone ovata & $\mathrm{X}$ & & $\mathrm{P}$ \\
\hline Olacaceae & S & Olax imbricata & $\mathrm{X}$ & & $\mathrm{P}$ \\
\hline Oleaceae & $\mathrm{C}$ & Jusminum angustifolium & & $\mathrm{X}$ & $\mathrm{P}$ \\
\hline Poaceae & $\mathrm{H}$ & Eragrostis tenella & $\mathrm{X}$ & & $\mathrm{P}$ \\
\hline Rhamnaceae & S & Ziziphus oenoplia & & $\mathrm{X}$ & $P$ \\
\hline Rhizophoraceae & $\mathrm{H}$ & Cassiopourea ceylanica & $\mathrm{X}$ & & $P$ \\
\hline \multirow[t]{3}{*}{ Rubiaceae } & $\mathrm{T}$ & Canthium dicoccum & & $\mathrm{X}$ & $\mathrm{P}$ \\
\hline & $\mathrm{T}$ & Morinda tinctoria & & $X$ & $\mathrm{P}$ \\
\hline & $\mathrm{T}$ & Tarenna asiatica & & $\mathrm{X}$ & $11, \mathrm{P}$ \\
\hline \multirow[t]{3}{*}{ Rutaceae } & S & Glycosmis mauritiana & & $X$ & $\mathrm{P}$ \\
\hline & $\mathrm{T}$ & Limonia acidissima & & $\mathrm{X}$ & $\mathrm{P}$ \\
\hline & $\mathrm{C}$ & Toddalia asiatica & & $\mathrm{X}$ & $11, \mathrm{P}$ \\
\hline \multirow[t]{2}{*}{ Salvadoraceae } & $\mathrm{T}$ & Azima tetracantha & & $\mathrm{X}$ & $P$ \\
\hline & $\mathrm{T}$ & Salvadora persica & & $\mathrm{X}$ & $\mathrm{P}$ \\
\hline \multirow[t]{3}{*}{ Sapindaceae } & $\mathrm{T}$ & Allophylus cobbe & & $\mathrm{X}$ & $\mathrm{P}$ \\
\hline & $\mathrm{T}$ & Lepisanthes tetraphylla & & $\mathrm{X}$ & $\mathrm{P}$ \\
\hline & $\mathrm{T}$ & Sapindus emarginatus & & $\mathrm{X}$ & $\mathrm{P}$ \\
\hline \multirow[t]{2}{*}{ Verbenaceae } & S & Lantana camara & & $\mathrm{X}$ & $\mathrm{P}$ \\
\hline & $\mathrm{H}$ & Stachytarpheta jamaicensis & & $\mathrm{X}$ & $\mathrm{P}$ \\
\hline Violaceae & $\mathrm{H}$ & Hybanthus enneaspermus & $\mathrm{X}$ & & $10,11, \mathrm{P}$ \\
\hline Vitaceae & $\mathrm{H}$ & Cissus quadrangularis & & $\mathrm{X}$ & $\mathrm{P}$ \\
\hline
\end{tabular}

The plant species on the Ussangoda serpentine site include those identified from this and other cited studies. The species on the nonserpentine regions in Ussangoda are based on the IUCN (2004) survey. 


\section{DISCUSSION}

A defining characteristic of a serpentine soil is a $\mathrm{Ca}: \mathrm{Mg}$ ratio of less than 0.6 (Brooks, 1987). The Ussangoda serpentine soil on the plains showed a ratio of 0.6 , and soil under the shrubs and trees a ratio of 1.8 to 1.9 . This was significantly below than that of the non-serpentine soil. Although the $\mathrm{Mg}$ content was not significantly different between the serpentine and non-serpentine soils, the $\mathrm{Ca}$ content was almost 15 times less on the serpentine plains. In a previous study on the soil chemistry of Ussangoda (Rajakaruna \& Bohm, 2002), the Ca concentration determined in the root zones of six species ranged from $112-210 \mu \mathrm{g} / \mathrm{g}$ (dry weight), which compares well with a mean value of $187 \mu \mathrm{g} / \mathrm{g}$ (dry weight) in this study. However, the $\mathrm{Mg}$ content determined in this study was 3-5 times of that was determined by Rajakaruna and Bohm (2002). In their study of four serpentine soils in Sri Lanka, Ussangoda showed the highest $\mathrm{Ca}: \mathrm{Mg}$ ratio of $1.3-2.4$ while the other three sites had $\mathrm{Ca}: \mathrm{Mg}$ as low as 0.07 (in Ginigalpelessa) due to a high $\mathrm{Mg}$ content. A serpentine site in Malaysia has shown a similar ratio of 0.6 (Brearley, 2005) and a serpentine site in Portugal (Lázaro et al., 2006) showed similar high values of exchangeable $\mathrm{Mg}$ over $\mathrm{Ca}$ in the soil to give a $\mathrm{Ca}: \mathrm{Mg}$ ratio of 0.7 whereas ratios of the non-serpentine sites were 2.4 to 6.9 . In a serpentine site in Italy similarly low values of 0.3 were found (Chiarucci et al., 1998) due to the high $\mathrm{Mg}$ content in the soil. The Ussangoda site falls within the basic definition for a serpentine soil based on $\mathrm{Ca}: \mathrm{Mg}$ ratio.

The CEC determined in this study is similar to that obtained previously on the same site (Rajakaruna \& Bohm, 2002). The other serpentine sites in Sri Lanka in Indikolapelessa and Ginigalpelessa had a higher CEC (Rajakaruna \& Bohm, 2002) of 25-50 cmol(+)/kg of soil. Higher CEC values of $16 \mathrm{cmol}(+) / \mathrm{kg}$ was also shown by a temperate serpentine soil (Lázaro et al., 2006). The soil pH values in Ussangoda determined previously (Rajakaruna $\&$ Bohm 2002) were more acidic $(4.3-4.9)$ than that was determined in this study, which could be due to time of sampling and determination of the $\mathrm{pH}$. In Malaysia, a $\mathrm{pH}$ value of 5.3 similar to Ussangoda was determined (Brearley, 2005). Acidic $\mathrm{pH}$ values were also obtained in serpentine soils in temperate conditions (Lázaro et al., 2006). The loss-of-ignition determined in a serpentine site in Italy of $10.8-23.7 \%$ (Chiarucci et al., 1998) was much higher than the 2.9 recorded in Ussangoda. This could be accounted for by the cooler temperate climate while Ussangoda is exposed to continuously warm temperatures. However, high loss-of- ignition values of $12.6 \%$ were determined in a Malaysian serpentine soil
(Brearley 2005). The physical and chemical properties of the Ussangoda serpentine soil are similar to that are found elsewhere. However, there is a wide range of values depending on the time and location of sampling within the site.

Brooks (1987) first identified three species on the Ussangoda (E. alsinoides) and Uda-Walawe (Cymbopogon flexuosus and Morinda tinctoria) serpentine sites in Sri Lanka. He concluded that the serpentine flora was impoverished in species number and endemism without further potential for botanical research. Further studies (Seneviratne et al., 2000) on the flora of Ussangoda identified 14 species confined to specific areas on the serpentine plain and of limited distribution. In a preliminary survey of four serpentine sites in Sri Lanka Rajakaruna and Bohm (2002) reported on the flora, soil characteristics and heavy metal uptake by the plants.

Flora on serpentine soils are generally poor in species diversity and show a high degree of endemism. While the flora on the Ussangoda soil is poor in species and families compared to the surrounding non-serpentine region, attention has been drawn to the fact that although Sri Lanka has a greater degree of biodiversity per unit area than other Asian countries, endemic species were not found on the serpentine soils (Rajakaruna \& Bohm, 2002).

From a previous study of the flora of four serpentine sites in Sri Lanka, Rajakaruna \& Bohm (2002) concluded that the floristic composition was typical of tropical serpentine habitats. Their study added at least 23 new genera from Sri Lanka to the list of plants known to occur on serpentine soils. Of the 51 species identified in this study, upto now, growing on the plains and as patches of shrubs and trees on the Ussangoda serpentine soil, two species, Vernonia zeylanica (Grierson, 1980) and Scolopia acuminate (Verdcourt, 1996) were found endemic to Sri Lanka while C. kleinii (Rudd, 1991) is apparently endemic to Sri Lanka and Southwest India.

Colour polymorphism of the flowers of E. alsinoides growing on the serpentine soil was previously reported (Seneviratne et al., 2000; Rajakaruna \& Bohm, 2002). Both studies refer to two colours, while this study identified three colour morphs. The non-serpentine species is also known to have two colours (Austin, 1980). Rajakaruna and Baker (2004) speculate if the colour morphs could be due to edaphic differences in their micro-habitat. However, in this study, the three flower types were observed in plants growing very close to 
each other as well as far apart. Seneviratne et al. (2000) found distinct flavonoid profiles and suggested they are "flavonoid races".

The plant tissue concentration of heavy metals $(\mathrm{Ni}$, $\mathrm{Fe}, \mathrm{Mn})$ growing on the serpentine soil were above the amount considered to be normal for non-serpentine plants (Greger, 2004). Such accumulation of heavy metals is characteristic of serpentine adapted plants (Brooks, 1987). Plants capable of accumulating over $1000 \mu \mathrm{g}$ metal/g dry leaf tissue are considered as hyperaccumulators (Baker \& Brooks, 1989). H. enneaspermus accumulated over 1000 ppm Ni and three other species accumulated $500-800$ ppm Ni (Table 2). The different Ni contents in the different species suggest that the plants have varied mechanisms of overcoming Ni toxicity in the soil by increased uptake and sequestering of the $\mathrm{Ni}$ (hyperaccumulators) or by excluding from uptake (species with low Ni). Previous studies (Seneviratne et al., 2000) found four other species in addition to $H$. enneaspermus, that were able to hyperaccumulate Ni. Rajakaruna and Bohm (2002) had found $H$. enneaspermus as a Ni hyperaccumulator besides E. alsinoides and Crotolaria biflora. While the status of $H$. enneaspermus is unequivocal as a $\mathrm{Ni}$ hyperaccumulator, the differences in the other species could be due to time and location of sampling or analytical methods. Since surface contamination of the plant tissue with the metal rich soil is a problem, in this study plant tissues were washed with EDTA to remove surface bound metals, which may account for the lower values determined. According to Rajakaruna and Bohm (2002), H. enneaspermus and E. alsinoides occur in serpentine sites in Queensland, Australia but are not Ni hyperaccumulators. They suggest that since many varieties of both species are known, the Sri Lankan species may represent a physiologically distinct form, perhaps an edaphic race.

After the primary mineralization of the serpentine rock, the elemental composition of the soil is also altered by the colonization of vegetation, which along with climate determines the present mineral composition (Chiarucci et al., 1998). There is a dynamic interaction between the soil and the vegetation determining the physical and chemical characters of the soil at a given time. Tropical serpentine soils are different from temperate soils, primarily due to the cooler climate and vegetation. However, more studies on tropical serpentine sites are necessary to better understand the tropical serpentine soils and their interaction with the flora that is established on these soils. The Ussangoda serpentine site has the basic soil attributes of a typical serpentine soil and has a particularly low Ca content. The floral diversity is restricted and shows adaptation to the soil conditions morphologically and physiologically. Amongst the species are hyperaccumulators as well as excluders of Ni.

\section{Acknowledgement}

We thank the Director, Department. of Archaeology for permission to collect field samples from the Ussangoda serpentine site, Dr. D.S.A. Wijesundera, Director General of the National Botanic Gardens, Peradeniya for permitting the use of the Herbarium for identification of the species. Dr. G.W.A.R. Fernando, Department of Physics, The Open University of Sri Lanka, Ms. Y.A.S. Samithri in the preparation of this manuscript and Mr. R.B. Hapukotuwa for field assistance. Financial assistance provided by the British Ecological Society, the Institute of Fundamental Studies, and the National Science Foundation of Sri Lanka (RG/2006/EB/08) is gratefully acknowledged.

\section{References}

1. AESL (1999). Methods for the analysis of soil, plant, water and environmental samples. Agricultural and Environmental Services Laboratories, College of Agriculture and Environmental Sciences, University of Georgia. Available at (http://aesl.ces.uga.edu/protected/ methods/stl-soil.html). Accessed on 1 May 2011.

2. Amacher M.C. (1996). Nickel, Cadmium and Lead. Methods of Soil Analysis: Chemical Methods, part 3. pp. 739-768. Soil Science Society of America and American Society of Agronomy, Madison, Wisconsin, USA.

3. Anderson J.M. \& Ingram J.S.I. (1993). Tropical Soil Biology and Fertility: A Handbook of Methods. p. 221. CABI Publishing, Wallingford, UK.

4. Austin D.F. (1980). Convolvulaceae. A Revised Handbook to the Flora of Ceylon, vol. I. (eds. M.D. Dassanayake \& F.R. Fosberg), pp. 288-363. Amerind Publishing Co., New Delhi, India.

5. Baker A.J.M. \& Brooks R.R. (1989). Terrestrial higher plants which accumulate metallic elements - a review of their distribution, ecology and phytochemistry. Biorecovery 1: 81-126.

6. Brearley F.Q. (2005). Nutrient limitation in a Malaysian ultramafic soil. Journal of Tropical Forest Science 17 (4): 596-609.

7. Brooks R.R. (1987). Serpentine and its Vegetation: a Multidisciplinary Approach, p. 224. Dioscorides Press, Portland Oregon, USA.

8. Chiarucci A., Riccucci M., Celesti C. \& de Dominicis V. (1998). Vegetation-environment relationships in the ultramafic area of Monte Ferrato, Italy. Israel Journal of Plant Sciences 46: 213-221.

9. Dissanayake C.B. \& Van Riel B.J. (1978). Petrology and geochemistry of a recently discovered nickeliferous 
serpentinite from Sri Lanka. Journal of the Geological Society of India 19: 464-471.

10. Dissanayake C.B. (1982). The geology and geochemistry of the Uda Walawe serpentinite, Sri Lanka. Journal of the National Science Council of Sri Lanka 10(1): 13-34.

11. Greger M. (2004). Metal availability, uptake, transport and accumulation in plants. Heavy Metal Stress in Plants (ed. M.N.V. Prasad), pp. 462. Narosa Publishing House, New Delhi, India.

12. Grierson A.J.C. (1980). Compositae. A Revised Handbook to the Flora of Ceylon, vol. I (eds. M.D. Dassanayake \& F.R. Fosberg), pp. 111-278. Amerind Publishing Co., New Delhi, India.

13. Iqbal M.C.M., Kulasekara L., Rajakaruna N. \& Iqbal S.S. (2006). Plant-soil relations of a serpentine site in the southern coast of Sri Lanka. Fifth International Conference on Serpentine Ecology, Siena, Italy, 9-13 May. University of Siena, Siena, Italy. p. 42.

14. IUCN (2004). The Environmental Profile of Rekawa, Ussangodaand Kalametiya (RUK) Coastal Ecosystems. pp. 7-10, 111-117. International Union for the Conservation of Nature, Sri Lanka Country Office, 53, Horton Place, Colombo 7.

15. Kalra Y.P. \& Maynard D.G. (1991). Methods manual for forest soil and plant analysis. Information report NORX-319. Forestry Canada, Northwest region, Edmonton, Alberta, Canada.

16. Kruckeberg A.R. (1984). California Serpentines: Flora, Vegetation, Geology of Soils, and Management Problems, p. 180. University of California press, Berkeley, California, USA.

17. Lázaro J.D., Kidd P.S. \& Martínez C.M. (2006). A phytogeochemical study of the Trás-os-Montes region (NE Portugal): Possible species for plant-based soil remediation technologies. Science of the Total Environment
354: 265-277.

18. Munasinghe T. \& Dissanayake C.B. (1979). Is the highland-eastern Vijayan boundary in Sri Lanka a possible mineralized belt? Economic Geology 74: 1495-1496.

19. Munasinghe T. \& Dissanayake C.B. (1980). Is the highland-eastern Vijayan boundary in Sri Lanka a possible mineralized belt? - a reply. Economic Geology 75: 775-777.

20. Proctor J. \& Woodell S.R.J. (1975). The ecology of serpentine soils. Advances in Ecological Research 9: 255-366.

21. Proctor J. (2003). Vegetation and soil and plant chemistry on ultramafic rocks in the tropical Far East. Perspectives in Plant Ecology, Evolution and Systematics 6: 105-124.

22. Rajakaruna N. \& Baker A.J.M. (2004). Serpentine: a model habitat for botanical research in Sri Lanka. Ceylon Journal of Science 32: 1-19.

23. Rajakaruna N. \& Bohm B.A. (2002). Serpentine and its vegetation: a preliminary study from Sri Lanka. Journal of Applied Botany 76: 20-28.

24. Rudd V.E. (1991). Fabaceae. A Revised Handbook to the Flora of Ceylon, vol.VII (eds. M.D. Dassanayake \& F.R. Fosberg), pp. 34-381. Amerind Publishing Co., New Delhi, India.

25. Seneviratne A.S., Nandadasa H.G., Fernando W.S., Sanjeevani H.H.V.M. \& Rajapakse R.L.H.R. (2000). The serpentine vegetation of Ussangoda (Hambantota District) and nickel accumulating plant species. Proceedings of the Sixth Annual Forestry and Environmental Symposium, Kandy, Sri Lanka, 29-30 December. University of Sri Jayawardenepura, Nugegoda. p.1.

26. Verdcourt B. (1996). Flacourtiaceae. A Revised Handbook to the Flora of Ceylon, vol.X (eds. M.D. Dassanayake \& W.D. Clayton), pp. 199-235. Oxford and IBH Co., New Delhi, India. 